\title{
Peningkatan Efektivitas Guru Dalam Melakukan Penilaian Hasil Belajar Melalui Pendekatan IImiah Dan Pendekatan Klinis dengan Supervisi Pengajaran
}

\author{
Anak Agung Istri Agung Wahyuni ${ }^{1}$ \\ 'SMP Negeri 1 Payangan, \\ Gianyar, Indonesia \\ email: aaiawahyuni98@gmail.com
}

\begin{abstract}
Abstrak
Dalam melakukan tugasnya kualitas guru-guru terfokus pada 2 hal yaitu komitmen dan kemampuan. Bisa suatu ketika guru mempunyai komitmen tinggi tetapi kemampuannya kurang mendukung (misalnya keadaan sakit), maka kualitas guru menurun. Sebaliknya bisa saja komitmennya rendah tapi semangatnya tinggi sehingga motivasi yang dilakukan juga tinggi. Peneliti merasa sangat perlu adanya supervisi tentang kegiatan guru karena supervisi yang dilakukan oleh kepala sekolah terhadap guru-guru arahannya seperti tuntutan-tuntutan sekolah di satu pihak sedangkan di pihak guruguru, di dalam diri mereka ada suatu kemampuan untuk menjalankan atau tidak melaksanakan tuntutan kepala sekolah. Penelitian tindakan dalam bidang supervisi yang penulis gunakan adalah kombinasi antara pendekatan ilmiah dengan pendekatan klinis. Teknik supervisi yang digunakan adalah kombinasi antara teknik supervisi individual, pertemuan dan pendapat siswa. Instrumen yang digunakan adalah kuesioner dengan tipe isian. Jenis data yang dikumpulkan adalah data kualitatif dan data kuantitatif. Penelitian ini dilakukan selama 6 bulan melalui 2 siklus. Siklus I dengan supervisi individual, pertemuan formal, pendapat siswa. Siklus ke II supervisi individual, pertemuan formal dan pendapat siswa. Keberhasilan yang dicapai adalah meningkatnya kemampuan guru-guru dari awalnya rata-rata hanya mencapai 74,12, pada siklus I telah meningkat menjadi 81,87 dan pada siklus ke II meningkat menjadi 94,37 . Inovasi lain yang dilakukan dalam penelitian ini adalah menghitung signifikansi keberhasilan dengan teknik uji signifikansi.
\end{abstract}

Kata Kunci: Pendekatan Ilmiah, Pendekatan Klinis, Kemampuan Melakukan Penilaian Hasil Belajar.

\begin{abstract}
In carrying out its duties, the quality of teachers focuses on 2 things, namely commitment and ability. It could be that one day a teacher who has the ability, but the ability is not supportive (for example, is sick), then the teacher's quality will decline. In fact, it could be that the commitment is low but the enthusiasm is high so that the motivation is high. Researchers feel that there is a great need for supervision of teacher activities because the supervision given by the principal of the direction of the teachers is as done by school orders on the one hand while on the part of the head-teacher, within them there is an ability to run or not run the school. The action research in the field of supervision that the author uses is a combination of a scientific approach with a clinical approach. The supervision technique used is a combination of individual supervision techniques, meetings and student opinions. The instrument used was a questionnaire with a type of filling. The types of data collected are qualitative data and quantitative data. This research was conducted for 6 months through 2 cycles. Cycle I with individual supervision, formal meetings, student opinions. The supervisor of the second cycle of individual, formal meetings and student opinions. The success that was achieved was the ability of the teachers from the initial average of only 74.12 , in cycle I had increased to 81.87 and in cycle II increased to 94.37. Another innovation made in this study is calculating the sure significance with the significance test technique
\end{abstract}

Keywords: Scientific Approach, Clinical Approach, Ability to Assess Learning Outcomes.

\footnotetext{
${ }^{*}$ Corresponding author.
}

Received 03 Februari 2020; Accepted 31 July 2020; Available online 1 September 2020 (c) 2020 MPI. All Rights Reserved 


\section{Pendahuluan}

Ketidakberhasilan perbaikan mutu pendidikan telah membuat para pendidik cukup tercengang, hal ini membuat kita setuju terhadap pencanangan Departemen Pendidikan Nasional, tentang Managemen Peningkatan Mutu Pendidikan. Di sini peningkatan mutu pendidikan diarahkan kepada menggali kemampuan yang ada di sekolah. Berbeda dengan gaya yang terdahulu di mana pendidikan itu orientasinya pada input (input oriented). Yang tertera dalam input oriented misalnya: penyediaan buku-buku dan alat belajar lainnya, penyediaan sarana pendidikan, pelatihan guru dan tenaga kependidikan yang lain. Dengan ini terpenuhi maka diharapkan memperoleh output yang bermutu. Dengan pencanangan manajemen peningkatan mutu yang telah dipaparkan, maka sekolah akan menjadi pusat untuk bisa mutu pendidikan itu meningkat. Peningkatan mutu pendidikan sudah pasti banyak ditentukan oleh mutu guru dalam banyak hal (Ali, 1995). Secara khusus dalam penelitian ini dibahas peningkatan mutu guru dalam melakukan inovasinya proses pembelajaran, kemampuan melaksanakan penilaian, kemampuan melaksanakan evaluasi dan kemampuan guru dalam melaksanakan tindak lanjut terhadap proses pembelajaran yang telah dilakukan (Muhammad, 1983).

Perlu diketahui bahwa bagaimanapun giatnya para Kepala Sekolah melakukan tugasnya, walaupun ditambah dengan penelitian, belum tentu juga keberhasilan perilaku guru itu akan dapat dirubah dalam waktu yang singkat aritnya jika pengawasan dihentikan maka perilaku guru itu bisa berubah karena tingkah laku manusia dipengaruhi oleh banyak faktor.

(Faisal et al., 1982) memberi gambaran tentang tingkah laku manusia sebagai berikut:

1. Antara manusia yang satu dengan manusia yang lainnya terdapat perbedaan-perbedaan di dalam perasahaan, tekad, semangat, motivasi dan sebagainya. Karenanya, suatu prediksi yang tepat mengenai diri seseorang, belum tentu tepat untuk orang lain.

2. Dalam menyikapi sesuatu, tak seorang pun dan tak selamanya bertingkah konsisten dari waktu yang satu ke waktu yang lainnya. Sebab tingkah laku manusia pada sesuatu situasi, diwarnai oleh interaksinya dengan elemen-elemen lingkungan di suatu tempat dan saat tertentu. Hal yang demikian itu seringkali menjadi begitu sukar diprediksikan.

3. Tingkah laku manusia yang sedang diselidiki, bisa ikut dipengaruhi oleh proses penelitian itu sendiri. Adanya perhatian yang memusat dari peneliti ke orang-orang yang sedang diobservasi, lebih-lebih bila diketahui bahwa tingkah lakunya sedang diselidiki, sudah tentu memberi pengaruh terhadap tingkah laku yang mucnul di saat penelitian berlangsung.

4. Ilmu-ilmu tingkah lakum selama ini dibatasi juga oleh sejumlah konsep-konsep yang seringkali kurang memadai definisi-definisinya. Padahal pengembangan teori-teori yang kuat dan tegas, jelas memerlukan definisi-definisi yang benar-benar operasional. Ciri-ciri tingkah laku yang tercermin dalam konsep-konsep seperti kecerdasan, belajar, permusuhan, keraguan, motivasi, dan ciri-ciri tingkah laku lainnya yang serupa, kesemuanya tidak dapat diobservasi secara langsung. Konsep-konsep sebagaimana yang dicontohkan tadi, peyimpulannya paling-paling berdasarkan biji-biji tes atau hasil observasi sejumlah tindakan atau gerak badaniah yang mengindikasikan sesuatu konsep dimaksud.

Dalam keputusan Menteri Negara Pendagunaan Aparatur Negara dan Reformasi Birokrasi Nomor 21 Tahun 2010 tentang Jabatan Fungsional Guru dan Angka Kreditnya disebutkan bahwa Kepala Sekolah diberi tugas, tanggung jawab, dan wewenang secara penuh untuk melakukan Pengawasan, penilaian dan pembinaan. Dari tugas-tugas inilah Kepala Sekolah sudah semestinya membantu untuk keberhasilan terhadap apa yang telah dicanangkan oleh sekolah-sekolah tadi, termasuk peningkatan kemampuan guru melaksanakan inovasi proses pembelajaran, kemampuan guru melaksanakan penilaian, kemampuan guru melaksanakan evaluasi proses pembelajaran serta kemampuan guru melakukan tindak lanjut terhadap proses pembelajaran guru telah dikerjakannya. 
Mengacu pada tugas yang dibebankan pada para Kepala Sekolah baik oleh Menteri Pendidikan maupun oleh harapan-harapan yang dilontarkan oleh kepala-kepala sekolah, maka peneliti berupaya sekuat tenaga, dengan pengorbanan waktu, pikiran dan biaya yang dikeluarkan sendiri untuk memenuhi tuntutan-tuntutan tersebut; dengan membantu salah satu tugas yang dibebankan yaitu peningkatan kemampuan guru melaksanakan inovasi proses pembelajaran, kemampuan guru melaksanakan penilaian, kemampuan guru melaksanakan evaluasi proses pembelajaran serta kemampuan guru melakukan tindak lanjut terhadap proses pembelajaran guru telah dikerjakannya.

\section{Metode Penelitian}

Penelitian yang dilakukan termasuk jenis penelitian tindakan. Penelitian tindakan ini terfokus pada penelitian tindakan sekolah. Salah satu contoh penelitian tindakan adalah desain yang dibuat oleh Depdiknas seperti berikut.

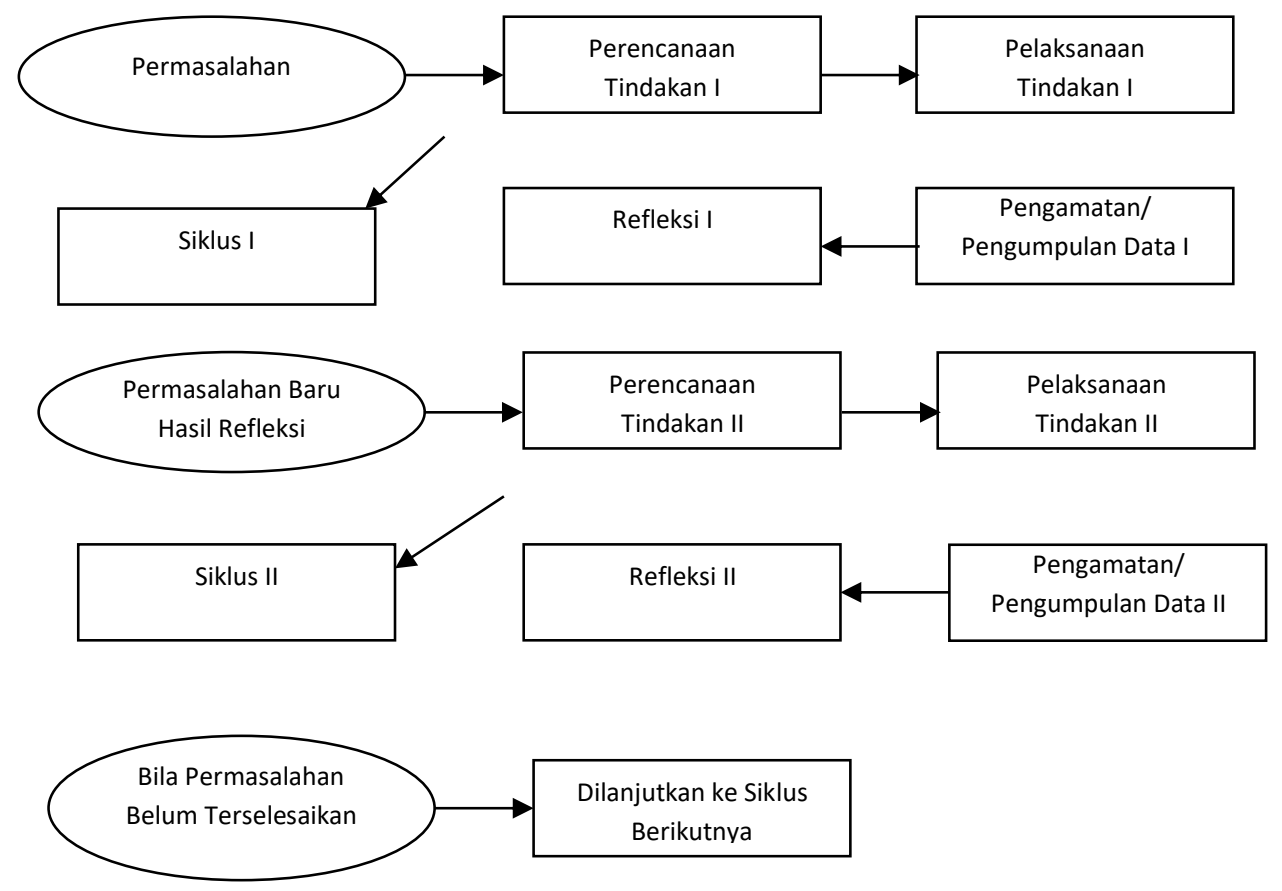

\section{Gambar 01. Gambar Desain Penelitian Tindakan dari Depdiknas}

Langkah-langkah supervisi yang ditempuh dalam penelitian ini :

1. Pendekatan ilmiah dan pendekatan klinis, dilaksanakan secara simultan dan saling melengkapi. Pendekatan klinis akan dapat dilakukan dengan lebih optimal jika didukung oleh fakta-fakta empiris tentang kwalitas profesi guru-guru tersebut.

2. Kombinasi pendekatan dan teknik-teknik supervisi yang dapat ditempuh adalah sebagai berikut.

a. Pada akhir semester II tahun pelajaran $2017 / 2018$ yaitu pada bulan Juni penyusunan proposal sudah dimulai sambil mengadakan Pengawasan terhadap persiapan ulangan umum di sekolah-sekolah, sambil berbincang-bincang dengan kepala sekolah tentang kinerja guru-guru. Diteruskan dengan persiapan-persiapan yang diperlukan seperti kuensioner, fotokopian-fotocopian dan lain-lain.

b. Selanjutnya masih pada semester II tahun pelajaran 2017/2018 digunakan teknik meminta pendapat siswa secara terbuka dengan tanya jawab lisan. Komponen yang diamati adalah kinerja guru dalam melaksanakan proses belajar mengajar.

c. Supervisi dilanjutkan dengan teknik berdiskusi secara formal secara rutin dalam pertemuan setiap kali peneliti/Kepala Sekolah datang ke sekolah. Dalam pertemuan 
ini kembali dipertegas tentang kompetensi guru, sehubungan dengan adanya masukan-masukan yang belum sesuai harapan.

3. Pada tahap akhir dari semester II tahun pelajaran 2017/2018 yaitu pada diulangi mengecek kebenaran pelaksanaan pembelajaran yang dilakukan guru utnuk mengetahui kemajuan yang dicapai guru. Setelah bulan itu, peneliti masih mendapat 1 bulan lagi untuk menyelesaikan atau merampungkan semua karya ini, sehingga pada bulan berikutnya barulah penelitian ini dapat diselesaikan mengingat pada bulan Juni sudah hampir tidak ada proses belajar mengajar karena murid-murid sudah dipersiapkan menghadapi ulangan-ulangan.

\section{Hasil Dan Pembahasan}

Seringnya peneliti selaku Kepala Sekolah berkunjung ke kelas membaut terjadinya perubahan prilaku guru, ini relihat dari hasil tes siklus ke-2. Dengan pengamatan langsung di lapangan, jarang terjadi kelas kosong dan persiapan-persiapan pengajaran yang mesti dibuat oleh guru-guru sudah dilaksanakan, walaupun maish kurang lengkap atau masih photocopian dan bahkan ada satu atau dua guru yang dengan suatu alasan kelupaan membawa perangkat pengajarannya tetapi mereka semakin rajin datang ke sekolah karena akan dinilai oleh siswasiswi mereka (Kusmintardo \& Burhanuddin, 1998).

Perubahan nilai kelihatan cukup bagus dan kebanyakan guru-guru rata-rata nilainya naik dari kisaran 14 ke atas menjadi kisaran 16 ke atas, hal ini juga jelas merupakan bukti bahwa komitmen guru-guru sudah lebih baik dari sebelumnya (Aziz, 1995). Memang merupakan hal yang cukup payah untuk mengupayakannya karena Kepala Sekolah harus lebih rajin datang ke ke kelas. Upaya peningkatan kemampuan guru-guru juga bagus dilakukan dengan cara lebih sering mengawasi dan melakukan rapat-rapat di mana upaya memberi penekanan-penekanan yang lebih sering dapat dilakukan.

Peningkatan nilai dari C ke A memang belum banyak terjadi pada guru-guru (Dantes, 2000). Rupanya agak sulit bagi guru-guru meningkatkan nilainya dari rata-rata 81,87 menjadi rata-rata 94,37. Jadi untuk mencapai peningkatan 2 sudah merupakan hal yang tidak mudah. Sangat luar biasa bila banyak dari guru-guru bisa meningkat mencapai klasifikasi $A$ dari klarifikasi $\mathrm{C}$, namun dari peningkatan $\mathrm{B}$ ke $\mathrm{A}$ ada yang bisa melakukannya. Bila PengawasanPengawasan, pembinaan-pembinaan cukup sering dilakukan otomatis peningkatan kemampuan guru-guru akan bagus namun bila Pengawasan-Pengawasan dan pembinaanpembinaan hanya dilakukan oleh Kepala Sekolah karena keperluan tertentu dan sesudah itu menurun lagi pembinaan-pembinaan itu, bisa saja akan terjadi penurunan kemampuan karena tingkah laku manusia sangat dipengaruhi oleh faktor-faktor tertentu (Faizal, 1982).

Kebenaran keadaan di lapangan sudah tidak bisa dipungkiri lagi bahwa pada jaman demokrasi sekarang ini banyak guru-guru telah berani mengungkap kesalahan-kesalahan atasannya seperti kesalahan atau kekeliruan kepala sekolah, kekeliruan Kepala Sekolah yang datang ke lapangan, sok berkuasa, dll. Hal inilah yang mendasari ketidakpedulian para guru dengan suatu penilaian yang dilakukan pada diri mereka (Hendiyat, 1988). Mereka tahu kepada siapa mereka harus berbuat baik adalah kepada oang yang bisa menentukan kariernya. Mereka kurang peduli pada orang yang tidak memegang policy apalagi cuma datang untuk penelitian. Semakin sering didatangi maka semakin sering meninggalkan kelas dangan alasan-alasan lain. Hal inilah yang menyebabkan beberapa guru kemampuannya menurun walaupun tidak begitu menyolok.

Hasil yang diperoleh dari awal, siklus I dan siklus II dipaparkan dalam bentuk grafik seperti berikut. 


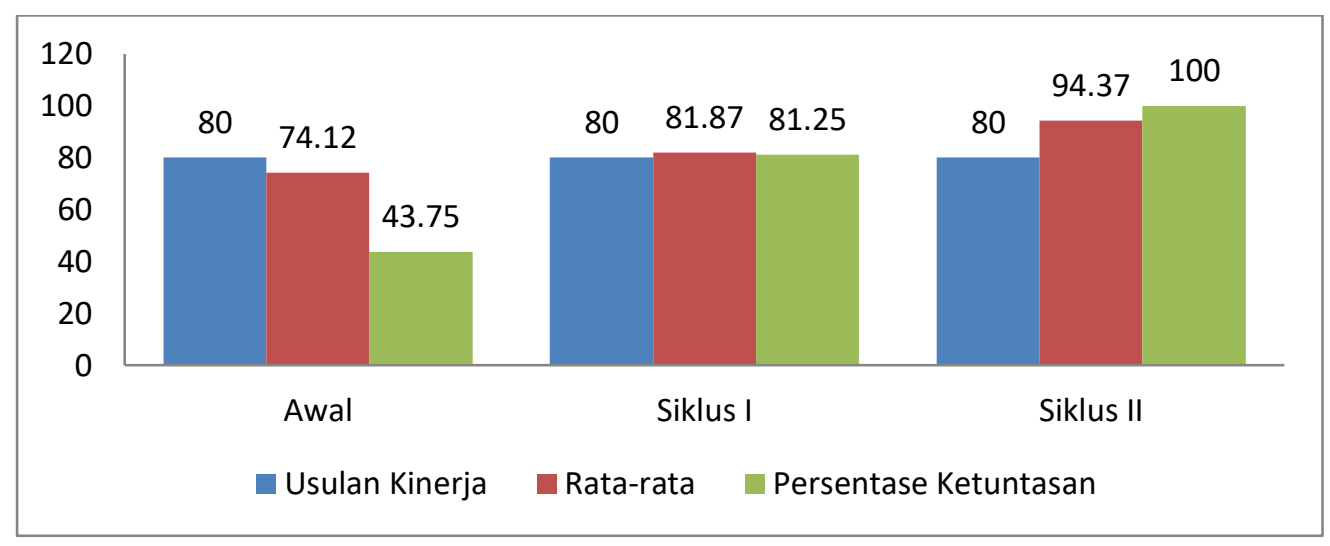

Grafik 01. Hasil penilaian efektivitas guru melaksanakan penilaian hasil belajar dari awal, siklus I, siklus II

Hasil penelitian ini diperkuat dari hasil penelitian yang telah dilakukan oleh (Tamrin, 2017) dengan judul Pengaruh Penerapan Supervisi Akademik Berbasis Modeling Inspiratif Terhadap Peningkatan Kemampuan MengajarGuru SD Gugus IVKecamatan MakassarKota Makassar. Hasil penelitian menunjukkan bahwa ada pengaruh signifikan penerapan supervisi akademik berbasis modeling inspiratif terhdapat peningkatan kemampuan mengajar guru. Hal ini terlihat pada nilai signifikansi lebih kecil daripada $(0,00<0,05)$ yang artinya $\mathrm{H} 1$ (artinya ada pengaruh signifikan penerapan supervisi akademik berbasis modeling inspiratif terhadap peningkatan kemampuan mengajar guru SD pada gugus IV Kecamatan Makassar Kota Makassar diterima.Selain itu, respon guru terhdap penerapan supervisi akademik berbasis modeling inspiratif sangat positif..

\section{Simpulan}

Dari hasil penelitian yang dipaparkan pada bab IV, beberapa simpulan dapat ditari yaitu: Penerapan kombinasi pendekatan ilmiah dan pendekatan klinis pada supervisi pengajaran dengan menggunakan teknik pertemuan formal dan teknik menggunakan pendapat siswa dapat meningkatkan kemampuan guru-guru SMP Negeri 1 Payangan dalam melakukan inovasi pembelajaran, penilaian proses pembelajaran, melakukan evaluasi hasil dan melaksanakan tindak lanjut. Harapan kepala sekolah agar Kepala Sekolah membantu mengoptimalkan peningkatan kemampuan guru-guru ternyata terbukti dengan efektif. Dari sekian guru yang penulis tanyai, perasaan guru-guru amat berbeda bila Kepala Sekolah memasuki ruang kelas dalam melakukan monitoring.

\section{Daftar Pustaka}

Ali Imron, 1995. Pembinaan Guru Indonesia, Penerbit Pustaka Jaya: Malang.

Ali, Muhammad, 1983, Guru Dalam Proses Belajar Mengajar, Penerbit Sinar Baru: Bandung.

Arikunto, Suharsini, 1992, Prosedur Penelitian, PT. Rineka Cipta: Jakarta.

Aziz Hoesein, Abdul, 1995, Karya Tulis IImiah Dibidang Pendidikan, Departemen Pendidikan dan Kebudayaan, Direktorat Jendral Pendidikan Dasar dan Menengah.

Dantes, Nyoman, 2000, Peningkatan Pembangunan Pendidikan Menyongsong Otonomi Daerah, PGRI Pengurus Daerah Tingkat I Bali.

Depdiknas, 2008. Kompetensi Evaluasi Pendidikan. Jakarta : Direktorat Tenaga Kependidikan Dirjen PMPTK.

Depdiknas, 2008. Perangkat Pembelajaran KTSP. Jakarta : Direktorat Pembinaan SMA. 
Depdiknas, 2008. Perangkat Pembelajaran. Jakarta : Direktorat Jenderal Manjemen Pendidikan Dasar dan Menengah. Direktorat Pembinaan Sekolah Menengah Atas.

Depdiknas, 2008. Perangkat Penilaian. Jakarta : Direktorat Pembinaan SMA.

Depdiknas, 2009. Membimbing Guru dalam Penelitian Tindakan Kelas. Jakarta : Pusat Pengembangan Tenaga Kependidikan, Badan Pengembangan Sumber Daya Menusia.

Faizal, Sanafiah dan Mulyadi Guntur Waroso. 1982. Metodologi PEnelitian Pendidikan. Surabaya : Usaha Nasional.

Hendiyat Soetopo \& Wasty Soemanto, 1988, Kepemimpinan dan Supervisi Pendidikan, PT. Bina Aksara Jakarta.

Ine I. YouSMPa \& Zainal Arifin, 1993, Penelitian dan Statistik Pendidikan, Penerbit Bumi Aksara: Jakarta.

Kartini Kartono, 1992, Psikologi Wanita, Jilid I, CV. Mandar Maju: Bandung.

Kusmintardjo \& H. Burhanuddin, 1998, Dasar-dasar Managemen II (Kepemimpinan), Direktorat Pendidikan Menengah Umum: Jakarta.

Tamrin. 2017. Pengaruh Penerapan Supervisi Akademik Berbasis Modeling Inspiratif Terhadap Peningkatan Kemampuan MengajarGuru SDGugus IVKecamatan MakassarKota Makassar. JIKAP PGSD: Jurnal IImiah IImu KependidikanVol,1. No,2. Tahun 2017. 